\title{
INTERPRETATION OF SYIQAQ AND ITS PROCEDURAL LAW AT RELIGIOUS COURT IN YOGYAKARTA
}

\author{
Haniah Ilhami*
}

\begin{abstract}
The objective of this research is to identify the interpretation of syiqaq as a legal reason in divorce lawsuit and its procedural law implemented by the Religious Courts in Yogyakarta. This is an empirical normative research, using the literature research method and field research through Focus Group Discussion (FGD). This research found that syiqaq is interpreted as a specific form of an endless quarrelling which caused danger for either husband or wife. In practice, judges combine procedural law in divorce lawsuit based on syiqaq into the procedural law in other legal reason.
\end{abstract}

Keywords: syiqaq, hakam, religious court.

\section{Intisari}

Penelitian ini bertujuan untuk mengetahui interpretasi syiqaq sebagai alasan gugatan cerai oleh hakim dan praktek hukum acara penyelesaian perkara perceraian dengan alasan syiqaq yang diterapkan pada Pengadilan Agama di Daerah Istimewa Yogyakarta. Penelitian ini merupakan penelitian hukum normatif empiris, menggunakan metode penelitian kepustakaan dan penelitian lapangan melalui kegiatan Focus Group Discussion (FGD). Hasil penelitian menunjukkan bahwa syiqaq diinterpretasikan sebagai perselisihan dan percekcokan antara suami istri yang telah menimbulkan bahaya mengancam baik pada para pihak. Dalam prakteknya, hakim menggabungkan proses acara penyelesaian perkara perceraian dengan menggunakan alasan syiqaq ke dalam proses beracara untuk perkara yang menggunakan alasan perselisihan terus menerus.

Kata Kunci: syiqaq, hakam, peradilan agama.

\section{Plokok Muatan}

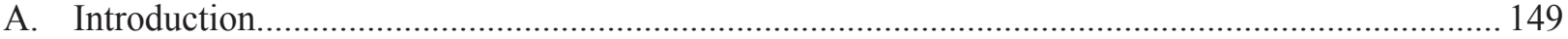

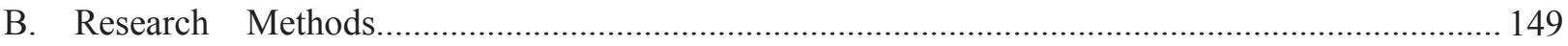

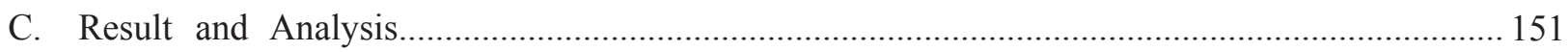

1. The Interpretation of Syiqaq as A Legal Reason on Divorce Lawsuit by The Judges of Religious Court Special Region of Yogyakarta................................................................... 15

2. The Trial Procedure of Divorce Lawsuit based on Syiqaq in Religious Court of Special Region of Yogyakarta.

3. Implementation of Hakam after The Implementation of Mandatory Mediation through Regulation Supreme Court No. 1 of 2008 concerning Procedural Court-Annex Mediation.......... 156

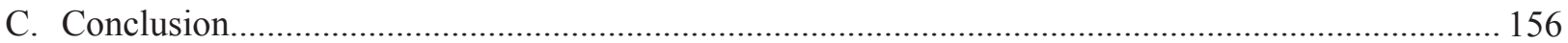

Correspondence address: haniah.ilhami@gmail.com 


\section{A. Background}

Religious courts is one specific institution of special courts in Indonesian civil court's system. One of its specification is a procedural law provisions implemented in its trial which some of them different from the provisions of civil law in general. In a divorce dispute filed and examined in the Religious Court, the specification shows in its are different forms of efforts of reconciliation with the other court, which known as specific efforts of reconciliation in divorce disputes. Divorce cases filed in the Religious Courts are divided into different legal reasons. Important things about those reasons is the difference procedural in a trial if a divorce lawsuit filed by the reason of syiqaq compared to other reasons. syiqaq which is also known as the endless quarrelling gives an additional consequences in the trial process, namely hakam. ${ }^{1}$ Hakam is an additional procedure that can be applied by the court in this kind of case. ${ }^{2}$

Provisions concerning syiqaq can be found in Law No. 7 of 1989 concerning Religious Courts. This law define syiqaq as an endless quarrelling and continuously between husband and wife. ${ }^{3}$ In the same provision, also regulate the procedural provision in its trial through the appointment of hakam. ${ }^{4}$ But, in many other laws and regulations relating to the provision of divorce in the Religious Court, there are no any specific definitions about syiqaq itself. It's important to explore how judges in religious court define and interprets the syiqaq in their case. Related to the interpretation, it also important to explore is the procedure of the examination and settlement of divorce lawsuit filed only the syiqaq as its legal reason.
Hakam is a form of efforts of reconciliations that included representatives of families from both the husband and wife, to help them find their for solving problems. Others also defined hakam as tahkim which is both has the same meaning ${ }^{5}$ hakam was appointed by the judge of the case after consultation and hearing to both parties. ${ }^{6}$ Through hakam, it is expected that peace can be achieved and divorce can be avoided wherever possible. As the development of regulations and procedures of the trials, the provisions of hakam as the peacemaker is questioned with other dispute resolution procedure, a mediation. Originally, mediation is one of many alternative dispute resolutions held outside of court. But based on the Supreme Court Rule No. 1 of 2008 on Procedures of Court Annexed Mediation, this procedure become expanded. By this rule, any efforts of reconciliations should use the third parties, an official mediator.

At the same time, hakam still exist because its provisions in the Law No. 7 of 1989 has not been cancelled yet. Related to the essence of hakam and mediation, its clearly showed that the obligation of mediation for all civil cases (with certain exceptions) may give effects to hakam. Hakam itself maybe abandoned or merged into this court-annexed mediation. ${ }^{7}$ It is still been debated since hierarchy, the hakam is regulated through a law which while in the court annexed mediation only regulated at the level of the Supreme Court Rules. Based on those conditions, this research has analysed some main problems which are the interpretation if syiqaq as a legal reason in divorce lawsuit by judges in the Religious Court, the procedure of the examination and settlement of divorce lawsuit filed only the

M. Yahya Harahap, 2007, Kedudukan Kewenangan dan Acara Peradilan Agama (Undang-Undang Nomor 7 Tahun 1989), Pustaka Karini, Jakarta, p. 248.

Mahkamah Agung, 2010, Buku II Pedoman Teknis Administrasi dan Teknis Peradilan Agama, Mahkamah Agung, Jakarta, Ketentuan Hukum Keluarga No. 12 huruf (c), Mahkamah Konstitusi, Jakarta. Also see Law Number 30 of 1999 on Arbitration and Alternative Dispute Resolution (State Gazette of the Republic of Indonesia of 1999 Number 138).

Also defined by Ahmad Azhar Basyir, 2000, Hukum Perkawinan Islam, UII Press, Yogyakarta, p. 88. Also see Article 19 point (f) Government Regulation Number 9 of 1975 on Implementation of Law Number 1 of 1974 on Marriage.

4 Article 76 paragraph (2) the Law Number 7 of 1989 on Religion Court (State Gazette of the Republic of Indonesia of 1989 Number 49 , Supplement State Gazette of the Republic of Indonesia of Number 3400).

Ramdani Wahyu, "Pelaksanaan Hakam dan Mediasi di Pengadilan Agama", http://www.fshuinsgd.ac.id/2012/04/pelaksanaan-hakam-danmediasi-di-pengadilan-agama/, accessed on 1 October 2012.

Article 76 paragraph (2) the Law Number 7 of 1989 on Religion Court (State Gazette of the Republic of Indonesia of 1989 Number 49 , Supplement State Gazette of the Republic of Indonesia of Number 3400).

Article 2 paragraph (2) the Supreme Court Rule Number 1 of 2008 on Procedures of Court Annexed Mediation. 
syiqaq as its legal reason on Religious Courts in D.I. Yogyakarta, and last is the implementation of hakam after the obligation of court annexed mediation, especially after the Supreme Court Rules No. 1 of 2008 concerning Procedure of Court-Annexed Mediation.

\section{B. Research Method}

This research combine both of normative legal research and empirical legal research. Under these conditions, this research examine the development of some of the regulations of Islamic marriage law in the Indonesian legal system and its practices and implementations of the religious courts.

\section{Literature Research}

Literature research conducted in two (2) phases, before and after the field research. Literature research conducted prior to field research aims to provide the basic concepts and guides for researcher to carry out the next stage of research. Literature research conducted after the field research aims to analyse the results from the respondents and interviewees in accordance with the principles of Islamic inheritance law. In more detail, the literature research that has been done is as follows: (a) Research tools. This literature research uses general secondary data include official documents, the results of previous research, and other library materials; (b) Research material. Literature research consists of 3 (three) materials, which are the primary legal materials, secondary legal materials and tertiary legal materials, with systematics; primary legal materials are any regulations closely related to the study, include, laws and regulations: (1) Law No. 1 of 1974 concerning Marriage; (2) Law No. 7 of 1989 concerning Religious Courts as last amended by Law No. 50 of 2009 concerning the Third Amendment of Law No. 7 of 1989 concerning Religious Courts; (3) Presidential Instruction No. 1 of 1991 concerning the Compilation of Islamic Law.

Decision of the Administrative Officer, Decree, Circular Letter, and other binding legal materials, include: (a) Regulation of the Supreme Court
No. 1 of 2008 concerning Procedure in AnnexedCourt Mediation; (b) Decree of the Chairman of the Supreme Court Number: KMA/032/SK/IV/2006 on 4 April 2006 concerning the Enforcement of Book II Guidelines for Administration of Justice in Court. Religious Courts' Decisions in Special Region of Yogyakarta: (a) Decision No. 528/Pdt.G/2010/ PA.Yk; (b) Decision No. 172/Pdt.G/2010/PA.Btl.; (c) Decision No. 341/Pdt.G/2010/PA.Btl; (d) Decision No. 302/Pdt.G/2010/PA.Btl; (e) Decision No. 0357/Pdt.G/2011/PA.Wt.; (f) Decision No..0026/ Pdt.G/2011/PA.Wno; (g) Decision No. 1185/ Pdt.G/2011/PA.WNO.

Secondary legal materials, all materials that explain the primary legal material, include: (a) the books that discuss Islamic marriage law in general and procedural laws of religion in Indonesia in particular; (b) other results of legal research and opinion of legal experts to discuss related issues; (c) magazines, journals and newspaper articles related to the related problem, both nationally and internationally; (d) the writings contained in the internet sites related to the problem. Tertiary legal materials, any legal materials that give instructions and explanations of the primary and secondary legal materials, which include: (1) legal dictionary; (2) Indonesian dictionary; (3) encyclopaedia.

\section{Analysis Method}

Research done by find, select, analyse, collect, and compare all legal materials related to the research problem, to make the conclusions related to the problem. The research used a qualitative analysis method, which collected all the data, selected, and studied as a whole so that can give a comprehensive description. ${ }^{8}$

\section{Field Research}

Field research conducted through the Focus Group Discussion by inviting religious court judges, 1 (one) Judge from each Religious Courts in Special Region of Yogyakarta, include the Religious Court in Sleman, Religious Court in Bantul, Religious Court in Wonosari, Religious Court in Wates, and the Religious Court of Yogyakarta, and 
1 (one) High Religious Court Judges. In addition, this study will also involve speakers, which is the Islamic law lecturer from the Faculty of Law, University of Gadjah Mada. FGD raised the issue as a topic of discussion, include: (1) How does syiqaq interpretation as legal reason in divorce lawsuit by the religious court judge in Special Region of Yogyakarta?; (2) What are the basic considerations and legal arguments against this interpretation?; (3) How the litigants (plaintiff, defendant, and/or legal counsel) in understanding the interpretation? (4) How the application of the provisions of hakam into the trial of divorce lawsuit based on syiqaq as its reason on Religious Courts in Special Region of Yogyakarta? (5) Where is the position of hakam after the enactment of mandatory court-annexed mediation rules by the Supreme Court Rule No. 1 of 2008 ? From the results of field research, the data analysis is done by processed and analysed directly using the descriptive qualitative method. The process is conducted into a broad description, the it conclude the results comprehensively.

\section{Result and Analysis}

1. The Interpretation of Syiqaq as A Legal Reason on Divorce Lawsuit by The Judges of Religious Court Special Region of Yogyakarta

\section{a. Legal Basis of Syiqaq in Islamic Marriage Law and Religion Court Proceedings}

Divorce settlement using syiqaq as its reason based on both provisions in fiqih Islamic marriage law and national positive law. Those provisions in are: Firstly, based on fiqih provisions the Islamic marriage law. Fiqih provisions based on the Qur'an that explicitly defines syiqaq and its reconciliation's procedure in An-Nisa verse 35:

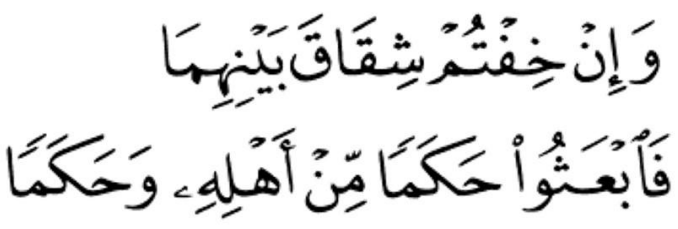

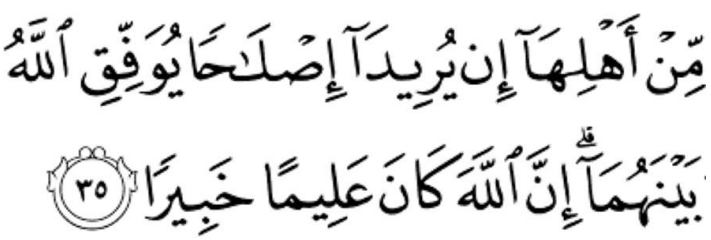

"If you fear a breach between them twain (the man and his wife), appoint (two) arbitrators, on from his family and the other from hers; if they both wish to peace, Allah will cause their reconciliation. Indeed Allah is Ever AllKnower, Well-Acquainted with all things".

This verse is the legal basis of syiqaq, especially about the. Here syiqaq is generally interpreted as a form of dispute and to solve them must be appointed hakam to reconcile them. This verse is also the basis of the consideration of the judges to interpret and implement the provisions of syiqaq and hakam as part of a divorce lawsuit. Secondly, based on the provisions of national positive law. Indonesian positive law, particularly related to the trial in religious court, adopted the provisions syiqaq in various provisions. The law defines syiqaq as an endless and continuously quarrelling between the husband and wife. ${ }^{9}$ Under this provision, it can be concluded that in general, syiqaq is a dispute between husband and wife to be reconciled.

\section{b. Syiqaq Interpretation by Judges in Religious Courts in Special Region of Yogyakarta}

The results showed that the judges in Religious Court of Special Region of Yogyakarta interpret syiqaq differently. This difference is closely related to other provisions in the law, which is the term named as Continuous Disputes that also as one reason for filing for divorce lawsuit. The existence of those two (2) terms raises some different syiqaq interpretation: Firstly, syiqaq is different from continuous disputes. Opinion stating that syiqaq substantively different from the continuous disputes based its argument on the nature of the disputes arising from the two 
(2) circumstances. Syiqaq is a special form of Continuous Disputes. In syiqaq, disputes between husband and wife is a sharp disagreement, the dispute which pose a danger and the danger threatens to physically and psychologically against one or even both parties, a husband and wife. ${ }^{10}$ This is in contrast to the Continuous Disputes reason. Continuous Disputes interpreted as a form of dispute that does not lead to danger in between the husband and wife.

Differences between syiqaq and Continuous Disputes also show on the trial procedure. In the examination of the case based on syiqaq, the proceedings must be done by listening to witness testimony from the families and people who have a working relationship with one of the parties. This provision is an exception to the general law of civil procedure that not allow families to witness.

Different provisions apply to the examination of divorce based on Continuous Disputes reason. Examination with using this reason use the general provisions of civil law that not allow the families and people who have a working relationship with one of the parties as a witness. Examination by reason of Continuous Disputes is not the part of specification in Religious Court so that the provisions of the examination of witnesses follows the principle of examination of witnesses in general.

During its development, the current judges are generally no longer distinguish between syiqaq and continuous disputes. Based on its meaning, syiqaq considered similar to continuous disputes. The implications is to equalize the trial process for both syiqaq and Continuous Disputes. Both process are done by appoint and hear testimony from witnesses of families.

Secondly, syiqaq is similar with continuous disputes. Dissenting opinion also expressed by some judges. In contrast to previous interpretations, this opinion is interpreted syiqaq as the same term with Continuous Disputes. This opinion was developed based on the doctrine that the opinion of a former Chief Justice, M. Yahya Harahap, which expressly states that there is no difference between syiqaq and continuous disputes as both are the same thing.

Based on these similarity, the provisions of trial for both reasons should be applied equally. Either case investigation based on syiqaq or Continuous Disputes, both has to listen to witness testimony from relatives or people nearby. In addition, the provisions regarding the appointment of hakam as a mediator can also be done in the examination of the case that uses both these reasons.

\section{c. Determination of Syiqaq by Judge in Religious Court of Special Region of Yogyakarta}

Generally, the judges use one (1) common criteria in deciding a case in the category syiqaq, which is the danger. The danger can be found through the trial process that there have been revealed any domestic violence between the husband and wife. In particular, the determination of the criteria should be done by exploring the testimony both from the witnesses and family about the shape and nature of the dispute. Judge must first define the form of dispute between husband and wife, does it a dispute or quarrel. Dispute is defined as loss of mutual respect from both husband and wife which is not showed physically, but can only be seen from their daily life. For example, there is no any conversation between them, or never been seen going out together. While the quarrel is defined as a physically dispute, for example a fight or a harsh debate between them. Syiqaq itself is a special form of the combination of dispute and quarrel which pose a danger either to

$10 \quad$ Also defined by Kamal Muchtar, 1974, Asas-Asas Hukum Islam, Karya Uni Press, Jakarta, p. 188. 
one or both parties. To be able to determine the value of the dangers posed in the dispute between husband and wife, the judge should be able to explore the fact in each case. The law does not set the criteria for determining the danger as has happened syiqaq. In practice, the danger is still based on case by case and there is no common perception among judges themselves.

2. The Trial Procedure of Divorce Lawsuit based on Syiqaq in Religious Court of Special Region of Yogyakarta

\section{a. Application of Hakam in the Trial} Process of Divorce Lawsuit based on Syiqaq

The application of hakam in religious court in the trial should be done by using the trial procedures, include: Firstly, when should the hakam appointed? The appointment of hakam conducted in accordance with Islamic fiqih of marriage law in the Quran Surat An-Nisa verse 35. In this verse, there is one (1) word that became the basis for determining when the annointment of hakam, the

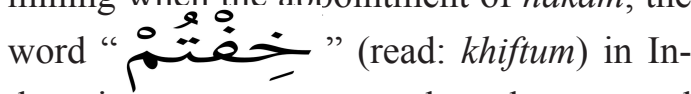
donesian, the word means have been scared or worried.

Based on the meaning of the word, the appointment of hakam can be done in two (2) possible states: (a) Hakam will be appointed when there is concern that disputes arising between husband and wife may cause hazards. In general, these provisions provide an opportunity to appoint hakam outside the litigation process in the Religious. The emergence of family concerns of both parties to the dispute has to be the basis for the appointment of hakam as a mediator between them. Hakam appointment does not require approval of a judge because it can be done alone by the family of the husband and wife family. Specifically in religious court proceedings, the appointment of hakam can be done by the judge since the judge believe that there is a danger arising from the dispute between husband and wife. Based on his belief, then hakam can be appointed at any stage of the examination in each round of trial at the time when the judges already have beliefs about the danger. (b) Hakam will be appointed only when real disputes arising between husband and wife has caused danger. Based on this interpretation, hakam may only be appointed if the real danger has been known to occur within marriage. Judge should give more efforts to explore the witnesses to find out the quality of the dispute between husband and wife. When applied in the trial process, the appointment of hakam can be done after hearing the testimony of witnesses, particularly witnesses from the family.

Secondly, who has an authority to appoint hakam? Provisions concerning the authorities can be seen from the 2 (two) regulations, the provisions of Islamic fiqih and the national positive law. Clearly is as follows: (a) Provisions of Islamic Fiqih. In fiqih, there are differences of opinion on the authorities to appoint hakam because there are differences of interpretation in interpreting the provisions of the Quran Surat An-Nisa verse 35, that the word " $\mathrm{i}$ ? (read: fab'atsu) This word is a command word which means "to appoint" which aimed to appoint hakam as a mediator in the case of syiqaq. The word raises two (2) different interpretations among the scholars: (1) The word is the command to appoint hakam addressed to both families. Implication of this provisions is that only the judge who has an absolute authority to appoint hakam; (2) The word is the command to appoint hakam addressed to the general public. Legal implications of this interpretation is that the appointment is not an authorized judge hakam, but an obligation of families to appoint hakam and reconcile both husband and wife. These differences then raised other doctrine of the 
scholars of Islamic law which states that there are 2 state on the appointment of hakam. In principle, the appointment of hakam was a family obligation. So that the family is the preferred party in the appointment of hakam. However, in cases where the family is not able to appoint hakam, the appointment will be submitted to the court and was appointed directly by the judge. (b) National Positive Law Provisions. In positive law, expressly said that the judge is a person authorized to appoint hakam. National positive law does not provide any other authority to appoint hakam family.

Thirdly, who may be appointed as hakam? Provisions about who can be appointed as hakam can be seen in terms of Islamic fiqih and positive law, include: (a) Under the provisions of Islamic fiqih. From the opinions of scholars and experts of Islamic law, the majority of scholars stated, hakam should be appointed from family, both husband and wife's family and the family; (b) Under the provisions of Positive Law. In positive law, hakam should not come only from family. Judge as the authorities to appoint hakam may appoint another party that will carry out their duties as hakam. In the appointment of hakam outside the family, the judge should take into consideration that the person does have a purpose and focus to reconcile disputes and trusted by both parties.

b. Trial Practice in Divorce Lawsuit by Syiqaq as Its Legal Reason on Religious Courts in Special Region of Yogyakarta

This research found that until now there is no case for divorce lawsuit that from the beginning using the reason syiqaq received and resolved by the Religious Courts in D.I. Yogyakarta. This is in contrast with the practice in other religious courts. Particularly in the Religious Courts outside Java, divorced lawsuit that originally filed using the reason syiqaq often found and examined by the judge. The absence of this condition caused by several reason, include: (1) Lack of knowledge about syiqaq. The parties, including each attorney does not know much syiqaq term, especially it specific procedural law. More popular term is Continuous Disputes. This resulted in every divorce that contains elements of quarrelling, has always aimed to be submitted in the Continuous Disputes reasons, not syiqaq. (2) Lack of uniformity of definition and category of syiqaq. This situation creates difficulties for judges in determining which procedural law should be used. Judge is authorized to perform interpretation, so it is possible the interpretation disparity among judges themselves. (3) The existence of trial principle which is Quick, Short and Low Cost in the Religious Court.

This principle emphasizes the efficiency of time spent in the examination of a Religious Court cases and costs to be incurred by the judges. Based on this principle, judges are required to promptly resolve cases assigned to him. This is reinforced by the provisions of the Supreme Court that a judge should be able to resolve cases assigned to him within a period of 6 (six) months from the case registered. If along that time the case has not found its conclusion yet, then Chairman of the Council of Judges shall report the delay to the Chairman of the Supreme Court through the Chairman of the Religious Court by stating the reasons. When a case containing a dispute filed with syiqaq reason, the legal implications of the event was the appointment of hakam will add more time to the trial and at the same time also adds to the costs of the parties.

Practice which is often done by the judges in the religious court is holding the trial of divorced lawsuit that use the Continuous Dispute combined by appointing hakam. The judges had originally accepted the case 
of divorce lawsuit by using Continuous Dispute's reason. However, after the hearing of witness testimony, the judge took the decision to appoint hakam. Under this practice, the judges has added a new procedural law, which is to apply the procedural law of syiqaq into divorce proceedings of the Continuous Dispute.

When referring to the procedural law of religious court, this practice is a violation of the provisions of law. The law provides that the appointment of hakam only done for the case that used syiqaq as its reason from the beginning. Expansion of the provisions related to the liability of judges to reconcile the parties, especially in divorce cases in accordance with the Mandatory Principles of Reconciling in Religious Court. To realize this principle, the appointment of hakam for divorce lawsuit that do not use the reason of syiqaq might be done.

\section{c. Religious Court Decision in Special Region of Yogyakarta related Pro- visions of Trial for the Case Using Syiqaq as its Reason}

Practice law in a trial of case using both syiqaq and Continuous Dispute in Religious Courts in Yogyakarta can be seen in several related decisions. generally, based on the decision, there are 3 (three) forms of the practice in the religious court judges in the Special Region of Yogyakarta, include: Firstly, hakam appointed to cases that do not use syiqaq as its reason. This practice can be seen in the Religious Court of Bantul Decision No. 172/Pdt.G/2010/PA.Btl. In the decision, it appears that the case filed by reason of Continuous Dispute. In the trial, the judge heard the testimony of witnesses family, i.e. father and brother of the applicant. During the trial, no testimony of witnesses and other evidence that shows there has been a dispute that contain elements of danger and threat. But in the trial, the Judge issued Injunc- tions Number. 172/Pdt.G/2010/PA.Btl dated July 21, 2010 which set a court case and appoint hakam, the brother of the applicant and Respondent's father. After doing their job, hakam reported that the results of peace efforts between the Applicant and the respondent has been difficult to live peacefully and maintain a household. Hakam reports later became a judge in a ruling consideration.

Secondly, examination of the case by reason of Continuous Disputes that contain elements of danger, but do not use hakam. This practice can be seen in some religious court decisions, where a judge has found in the trial that there has been a danger to either party, but the judge did not categorize the case as syiqaq and not appoint hakam. Forms of dangers that occur include: (a) Acts of physical violence, punching, kicking, choking, slapping, hair pulling, putting out cigarettes, and so forth; (b) Psychological violence, which often drive out of the house and asking to divorce. Thirdly, examination of the case on the reason of Continuous Dispute has attempted to appoint hakam, but did not succeed. In one of the court's decision, the case filed by the reason of Continuous Dispute and there is no element of danger to physical/mental in between husband and wife. In trial process, the judge has ordered the parties to bring representatives from each family to be appointed as hakam. Representative of applicant is always present at the hearing, while the defendant was not able to present theirs.

3. Implementation of Hakam after The Implementation of Mandatory Mediation through Regulation Supreme Court No. 1 of 2008 Concerning Procedural CourtAnnex Mediation

Hakam as a special form of trial procedure applied in a divorce lawsuit has a similar function to mediation. Hakam task in the proceedings 
of a divorce case is to reconcile the two parties to the dispute. The same duty is also charged on the mediation and implemented by the mediator. This condition gives impact in the mediation practice in the courts. Judges in the Special Region of Yogyakarta generally have the same opinion, that hakam and the mediator has the same functions and duties. Both are equally as the representative of the prin-cipal of Obligation to Reconciling, particularly those applied in the examination of divorce lawsuit. The difference between mediation hakam and will be seen in the procedural law applicable to both. Under religious law court proceedings, the difference between mediation and hakam and divided into 2 (two) categories: (1) Differences in the position of the legal basis. Hakam and mediation arranged in two (2) different levels of regulation. Hakam set out in the Law, while mediation is set in the Supreme Court Rules. Related to the Indonesian Legislation Hierarchy, the provisions of hakam governed by rules higher than mediation. (2) Difference in binding strength. Difference in binding strength bet-ween hakam and mediation provided in each legal provisions. In provisions of hakam, the nature of hakam is only facultative while the mediation is an obligation to be held by all judges.

\section{Conclusion}

Based on the research that has been done, it can be concluded that: Firstly, syiqaq as a reason for divorce lawsuit interpret as continuous dispute and quarrell between husband and wife that contains danger for both. One common danger might be found in the fact of trial that there have been acts of domestic violence between husband and wife is. Secondly, the trial procedure of divorce lawsuit using syiqaq as its legal reason based om the provisions regulated on the Law No. 7 of 1989 concerning Religious Courtm by appointing lifting hakam after hearing witness testimony. However, in practice, the appointment of hakam was also carried out on divorce lawsuit using other reason than syiqaq. Thirdly, after the implementation of the Supreme Court Rules No. 1 of 2008 on Procedures of CourtAnnexed Mediation, judges still have their right to appoint Hakam after they held the mediation process between both husband and wife.

\section{BIBLIOGRAPHY}

\section{A. Books}

Basyir, Ahmad Azhar, 2000, Hukum Perkawinan Islam, UII Press, Yogyakarta.

Harahap, M. Yahya, 2007, Kedudukan Kewenangan dan Acara Peradilan Agama (Undang-Undang Nomor 7 Tahun 1989), Pustaka Karini, Jakarta.

Mahkamah Agung, 2010, Buku II Pedoman Teknis Administrasi dan Teknis Peradilan Agama, Mahkamah Agung, Jakarta, Ketentuan Hukum Keluarga No. 12 huruf (c), Mahkamah Konstitusi, Jakarta.

Miles, Matthew B. \& A. Michael Huberman, 1992, Analisis Data Kualitatif, Universitas Indonesia Press, Jakarta.

Muchtar, Kamal, 1974, Asas-Asas Hukum Islam,
Karya Uni Press, Jakarta.

\section{B. Internet Articles}

Wahyu, Ramdani, "Pelaksanaan Hakam dan Mediasi di Pengadilan Agama", http://www.fshuinsgd.ac.id/2012/04/pelaksanaan-hakam-danmediasi-di-pengadilan-agama/, accessed on 1 October 2012.

\section{Act and Regulation}

Law Number 30 of 1999 on Arbitration and Alternative Dispute Resolution (State Gazette of the Republic of Indonesia of 1999 Number 138).

Government Regulation Number 9 of 1975 on Implementation of Law Number 1 of 1974 on Marriage. 
Law Number 7 of 1989 on Religion Court (State

Gazette of the Republic of Indonesia of 1989 Number 49, Supplement State Gazette of the Republic of Indonesia of Number 3400).
Supreme Court Rule Number 1 of 2008 on Procedures of Court Annexed Mediation.

Presidential Instruction Number 1 of 1991 on the Compilation of Islamic Law. 